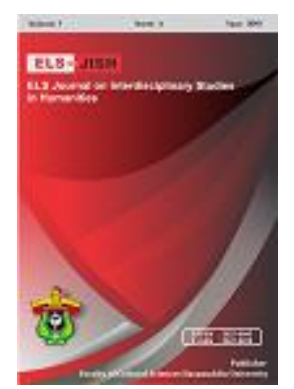

ELS-JISH

ELS Journal on Interdisciplinary Studies on Humanities

Volume 2 Issue 2, 2019

ISSN (print) : 2621-0843

ISSN (online) : 2621-0835

Homepage : http://journal.unhas.ac.id/index.php/jish

\title{
Code Variety Broadcasted by East Kalimantan Radio Stations
}

\author{
Sukron Marzuki ${ }^{1}$, Djatmika Djatmika², Sri Marmanto ${ }^{3}$ \\ 1.sukronmarzuki@gmail.com
}

\begin{abstract}
This research aimed at elaborating the variety of code-switching and code-mixing used in radio broadcast in East Kalimantan. This research used qualitative descriptive method and applied sociolinguistics study. In the analysis, the researcher employed Poplack and Muysken theory. Data sources were collected from radio broadcast in three distinctive radio stations representing three largest cities in East Kalimantan, such as Samarinda, Balikpapan, and Tenggarong. The type of data were conversation that appeared within the Pilihan Pendengar program from each of three stations: Gemaya 104.5 FM (Balikpapan), RB Radio 87.7 FM (Samarinda) and SBK 107.3 FM (Tenggarong). The research finds that there are varieties of code-switching, including: intra-sentential (40 data), intersentential (19 data) and extra-sentential (9 data). For code-mixing, this research finds three variants, which are alternation (24 data), insertion (14 data) and congruent lexicalization (8 data). The data are obtained from different languages, such as Indonesian, Javanese, Kutainese, English and Arabic.
\end{abstract}

Keywords: Code-Switching, Code-Mixing, Language Variety, Radio Broadcast.

How to cite: Marzuki, S., et al. (2019). Code Variety Broadcasted by East Kalimantan Radio Stations. ELS Journal on Interdisciplinary Studies in Humanities, 2 (2), 225-238.

\section{Introduction}

As an interdisciplinary study, sociolinguistics involves social, situational and cultural factors. The reason is that in social life human is not considered an individual feature but one of social members. Language is a tool of communication in the form of sound symbol for human speaking (Thesa, 2017). Language, as a tool of communication, reflexes who they are, what they talk, to whom they talk and what kind of circumstances they are in. The phenomena of communication can be observed directly or through certain media, such as television, printed media or radio.

Radio is a technology that is used to send signal with certain electromagnetic wave as a modulation and radiation result from electromagnetic (Yanti, Rusminto, \& Agustina, 2017). Radio facilitates people to communicate among them in wide range of space. Hence, a communication via radio is called one way communication. It means that a radio broadcaster is the only one who is actively involved in the communication. Meanwhile, the radio listeners passively receive anything they listen 
from the speaker (the radio broadcaster) via their radios. However, in certain radio program, like Pilihan Pendengar the radio listeners are allowed to talk to radio announcer via phone call. Concerning such phenomena, this research observed the communication process with its social context.

Language diversity appears on the use of Indonesian language, local language and foreign language (Subiyatningsih, 2018). The radio program, Pilihan Pendengar, holds conversations between radio announcer $(\mathrm{A})$ and the phone caller (C). They have dialogues in Indonesian and sometimes use different foreign languages, such as English and Arabic. Both English and Arabic are barely spoken, but for certain reason it is used by the speaker. Meanwhile, local language is frequently used to convey knowledge in institutions relating to social life such as religion and culture (Thesa, 2017).

East Kalimantan consists of people from different tribes like Dayaknese, Kutainese, Banjarnese, Bugisnese, Javanese and etc. The diversity of tribes within East Kalimantan means the diversity in languages too. There are Javanese, Kutainese, Banjarnese and Bugisnese as the first language (L1). Indonesian language functions as second language (L2) and it is mostly used between two or more participants from different L1. Meanwhile, English and Arabic are two foreign languages (FL) which are also found in East Kalimantan radio program. A speaker may have an ability to speak more than one languages, for example: Javanese (L1) and Indonesian (L2). This situation leads to bilingualism, a condition where two languages are used alternately by a speaker. Aside from bilingualism, there is multilingualism, a condition when more than two languages are used by a speaker within a conversation (Hanafi, 2017).

Language variation does not only occur within a multilingual society, but also it is found in a language. For example, Indonesian language has two variations, which are standard and non-standard. Standard Indonesian can be found in formal situation with serious conversation topic. Meanwhile, non-standard Indonesian is for less formal situation where the participants of speaking know they are having a light conversation. This kind of language variation is frequently found as daily language style. Such phenomenon is found in a radio conversation in which languages are exploited along the program. It relates to diglossia in which the use of variety is allocated to different communicative purposes (Alsahafi, 2016).

Diglossia depends on the language user realizing two kinds of different functioning language varieties. According to Saddiyah \& Rokhman (2018) a language has two varieties, which are high variety $(\mathrm{H})$ and low variety $(\mathrm{L})$. High variation is used in formal situation whereas low variation involves in non-formal setting. Therefore, standard Indonesian (based on KBBI and EYD) tends to be performed in certain ceremony with formal situation, such as organizational meeting, office meeting, national conference, etc. Non-standard Indonesian is close to daily language around friends, family, and community with non-formal situation.

In sociolinguistics, language is considered as code. Code is usually in form of language variation which is apparently used to communicate by a member of language community (Herawati, 2014). Thus, there are different codes that could be potentially found within conversation in the radio programs. One of the speakers may deliver their speech in Indonesian language but sometimes there will be another 
language (code) in the text. They talk spontaneously and as it is according to conditions at that time in a language they master (Sufiani \& Pujiati, 2018). Such phenomena lead to this research focus which is code-switching and code-mixing.

Code-switching and code-mixing frequently exist in conversations, for example: conversations within a radio program. In code-switching every language and the variant of language that is used has its own function, is performed mindfully and deliberately based on certain factors. The speakers rely on code-switching (CS) in order to express group identity (Caparaz \& Gustilo, 2017). Meanwhile, code-mixing consists of a main code which is used and functioned whereas the others code involved in the speech event is not influential as a code. Code-mixing takes place without a change of topic and can involve various levels of language such as phonology, morphology, grammatical structures or lexical items (Ansar, 2017).

Code-switching has been the topics of numerous researches. First, there is a research from Bastiar, Marmanto, \& Sumarlam (2018) that studies code-switching in selling and buying activity at Segiri market, East Borneo. They investigate local languages existing in East Borneo by focusing on code-switching. They do not bring the study into broader discussion, unlike what this research does. This research does not only talk about code-switching in East Kalimantan but also code-mixing in East Kalimantan. Besides, this research gets the data from radio broadcast that has different situational factors from selling and buying transaction in the market.

The next research is conducted by Yuliana, Luziana, \& Sarwendah, (2016). They evaluate Indonesian celebrity skills in speaking English based on codeswitching and code-mixing. The research goal is to know the kind of code-switching and code-mixing. However, the research only results two languages, Indonesian and English. There is no local language competency found in the research. Due to the case, this research finds the gap. Not only is one local language involved but also 2 local languages is found, such as Java language and Kutai language.

Code-switching and code-mixing has also been studied by (Ayeomoni, 2006). The research observes the uses of code-switching and code-mixing in groups of children in a community. It focuses on describing how code-switching and codemixing are manifested into their language performance. He puts the attention toward the social factors, notably bilingual acquisition in Nigerian childhood. It is different from this research because this research does not focus on children only but also people from different ranges of age. Hence, this research participants include radio broadcasters and phone callers involving in Pilihan Pendengar program.

This research aims at identifying code choice forms used in conversation held on Pilihan Pendengar, one of radio programs broadcasted in East Kalimantan. There are two kinds of code, which are code-switching and code-mixing. To input the data based on that categorization, the analysis refers to Poplack's theory of codeswitching and Musken's theory of code-mixing. According to Poplack (1980), there are three types of code-switching: (1) intra-sentential code-switching; (2) intersentential code-switching; and (3) extra-sentential code-switching. Meanwhile, Muysken (2000) has stated that code-mixing is divided into three types: (1) insertion; alternation and congruent lexicalization.

Furthermore, this research presents two benefits, either theoretically or practically. Theoretically, it helps learner and researcher to enhance further 
understanding about code-switching and code-mixing theory, especially the theories which are declared by Poplack and Muysken. Practically, this research helps radio listeners to simplify comprehension about Indonesian language, foreign language and local language which are used in radio program of Pilihan Pendengar.

\section{Method}

This research used descriptive qualitative method which is aimed at describing a lingual form which is determined in a research as it is (Wahidah, Djatmika, \& Marmanto, 2017). Utilizing lexis, word group and clause as the lingual data, this research attempted to discover and explain code choice (switching or mixing) holistically during the conversation between radio announcers and the phone callers. Speech component in this research was based on considerations about who performs code choice, where code choice occured and in what event code choice was used, what was the most dominant code and how code choice was used (Mahsusi, Djatmika, \& Marmanto, 2017)

Data source was in form of oral source. Such oral source was obtained through a radio broadcast from three largest radio stations in East Kalimantan, such as RB radio 87.7 FM (Samarinda), Gemaya 104.5 FM (Balikpapan) and SBK 107.3 FM (Tenggarong). This research focused on a radio program namely Pilihan Pendengar. It was one of radio program that contained conversation. The conversation occured between radio announcer $(A)$ and phone caller, first radio announcer $(A 1)$ and second radio announcer (A2) (more than one radio announcer), and all of them (those two radio announcers and phone caller. The conversation was held in frame of entertainment and more serious topics like politics and health. Besides, it also provided a program about education. In this case, they have to select different codes to fulfill in educational functions (Husnan, 2016). This program also consisted of music which could be requested by the audience via phone call.

Data were collected with observation, field note and recording technique. The researcher was non-participant and used recording media to collect the data from live radio broadcasts. Records of radio broadcast were taken randomly between July to August 2018. A smartphone was utilized to play the radio program and record it at once. Afterwards, the files of recording in smartphone were transferred to a laptop and sorted based on the time when the radio program was played. The research data included all words, word groups and clauses containing code-switching and codemixing. They could be observed through levels of voice order, word order, form order, sentence order, and discourse order (Wulandari, Marmanto, \& Sumarlam, 2016). All of them were converted into a text which was typed and printed on a paper.

Data were analysed through three steps. First, the researcher applied data reduction. In this phase, data were obtained and then amounts of data were reduced from unimportant and irrelevant data. Next, the data (after being reduced) were displayed in a table, as shown in table 1. The table showed numbers of data found based on the classification and it was presented further in the results and discussion part. There were 114 data found which were relevant to code-switching and codemixing discussion. A number of data were classified based on the language, such as Indonesian - Javanese, Indonesian - Indonesian, Indonesian- Kutainese, Indonesian - Arabic, and Indonesian - English. Code-switching and code-mixing were determined and classified by referring Poplack (1980) and Muysken (2000) 
theory. Finally, conclusion were drawn based on the strong and valid evidence proposed in the first step (Mills \& Hubberman in Moleong, 2014).

\section{Main Heading of the Analysis or Results}

This research shows new findings about language use in radio broadcast in East Kalimantan. Participants of the data use Indonesian, English, Arabic, Java language and Kutainese. There are code-switching and code-mixing use that are found. The total data found are 114 data consisting code-switching and code-mixing varieties. For code-switching, it appears in kind of intra-sentential code-switching (40 data), inter-sentential code-switching (19 data) and extra-sentential code-switching (9 data). Meanwhile, code-mixing is performed in kind of alternation (24 data), insertion (14 data) and congruent lexicalization (8 data). Those kinds of code and language varieties are shown in the table below.

Table 1. Code Variety Frequency

\begin{tabular}{|c|c|c|c|c|c|c|c|c|}
\hline \multirow[t]{2}{*}{$\mathrm{N}$} & \multirow[t]{2}{*}{ LV } & \multicolumn{3}{|c|}{ CS } & \multicolumn{3}{|c|}{$\mathrm{CM}$} & \multirow[t]{2}{*}{$\mathrm{T}$} \\
\hline & & IA & $\mathrm{IE}$ & $E$ & $A$ & 1 & $\mathrm{CL}$ & \\
\hline 1. & $\ln -\ln$ & 7 & 5 & 3 & 5 & 3 & 2 & 25 \\
\hline 2. & In-Jv & 4 & 4 & 2 & 6 & 0 & 4 & 20 \\
\hline 3. & In-K & 10 & 4 & 4 & 3 & 6 & 2 & 29 \\
\hline 4. & In-En & 4 & 3 & 0 & 6 & 5 & 0 & 18 \\
\hline \multirow[t]{2}{*}{5.} & In-Ar & 15 & 3 & 0 & 4 & 0 & 0 & 22 \\
\hline & $\mathrm{T}$ & 40 & 19 & 9 & 24 & 14 & 8 & \\
\hline
\end{tabular}

Note: $\mathrm{N}=$ Number, $\mathrm{T}=$ Total, $\mathrm{LV}=$ Language Variation, $\mathrm{CS}=$ Code-switching, $\mathrm{CM}=$ Code-mixing, $\mathrm{IA}=$ Intra-sentential Code-switching, $\mathrm{IE}=$ Inter-sentential Codeswitching, $\mathrm{E}=$ Extra-sentential Code-switching, $\mathrm{A}=$ Alternation, $\mathrm{I}=$ Insertion, $\mathrm{CL}=$ Congruent Lexicalization, In-In = Indonesia-Indonesian In-Jv = Indonesia-Javanese, In-Kt = Indonesia-Kutainese, In-En = Indonesia-English, In-Ar = Indonesian-Arabic.

\subsection{Indonesian - Indonesian}

Indonesian language is mostly used in radio pilihan pendengar radio program broadcasted in East Kalimantan. It is lingua franca that can be understood by people from different tribes living in East Kalimantan. It is found switched from standard language to non-standard language. It doesn't switch from Indonesian language to another language, but it switches from $H$ to $L$ variety or $L$ to $H$ variety in which both are Indonesian variety due to diglossia case. A standard Indonesian refers to $\mathrm{H}$ whereas the non-standard one refers to $L$. Relating to the phenomena it is 15 data found. Here is one of the data sample:

A1: Entah kenapa mereka tidak memberikan suaranya. Tapi semoga deh kedepannya tidak seperti itu ya happy partner.

(Whether or not they did not vote. Still, may he will not do it again in the future.) 
A2: Kita kayak sudah mencanangkan pilgub itu keren atau segala macemnya dan membagikan surat suaranya. Tapi ternyata mirisnya lebih banyak golputnya dari pada yang memberikan suara.

(We seem to have planned the governor election well or anything about it and distribute the ballot.)

\section{A1: Mungkin mereka sedang mencari kitab suci.}

(Probably, they are looking for a holy book.)

The data above show that there are switched codes from a non-standard to standard Indonesian language. There are two participants, A1 (radio announcer 1) and A2 (radio announcer 2), talking about politics, especially governor election. In the first statement "Entah kenapa mereka.... ya happy partner" A1 used non-standard Indonesian. It is indicated with word kenapa, deh and happy partner. A2 agree with what $A$ said before and he used non-standard Indonesian too. A1 responses it but with a standard Indonesian language Mungkin mereka sedang mencari kitab suci. It is considered as code-switching because the sentence is not a part of previous sentence. It is independent from being the previous code's sentence structure. Such code-switching is kind of inter-sentential. It is to express his unsatisfied with the politic situations at that time by using standard Indonesian language. Meanwhile it is taken from a song lyrics namely Kera Sakti.

According to the data, the speaker switches standard Indonesian to nonstandard Indonesian because he wants to generate a humour in their conversation. The presence of humour in their conversation becomes a good solution since the conversation begins more seriously with unsatisfactory statement due to a lot of election voters that do not vote. Therefore, switching a code is beneficial to create a comfortable conversation while entertaining radio listeners too. Switching standard Indonesian to non-standard Indonesian can change the conversation direction and situation from formal to non-formal setting.

In the conversation between $\mathrm{A} 1$ and $\mathrm{A} 2$, there are also mixed codes found. There are 10 data found about code-mixing from $\mathrm{H}$ (standard Indonesian) to $\mathrm{L}$ (nonstandard Indonesian). Here is one of the example.

A1: Sekarang kan kita ini punya hak suara. Tau gak sih kalau dari.... (Interrupted by A2)

(Now we have voting rights. Do you know that from....) (Interrupted by A2)

A2: Ok kalau kita akur partner.

(Ok, if we get along then we will be partner.)

A1: Sumber data itu mengatakan bahwa kemarin pada saat pilkada itu banyak golputnya loh Nas.

(The data source states in last regional election yesterday there are a lot of abstention, Nas.) 
Based on the data above, there are mixed codes indicated by the bold word gak and Ioh which are non-standard Indonesian. Both words are different code mixed between previous code (standard Indonesian) and become a part of previous code. Therefore they are considered as code-mixing. The type of both mixed codes is insertion since it comes in form of word. A1 shows his arguments about voting right seriously which is followed by explaining data in his final statement. He tries to control the discussion with his idea to make his statement accepted by A2. Hence, he explains it in standard Indonesian but he mixes it with two non-standard Indonesians gak and loh for strengthening his statement that there are many abstentions in the last election.

\subsection{Sub-heading of the discussion}

Javanese language is a local language which is also used in east Kalimantan. There are a lot of Javanese people that come to stay there for short period and some of them stay permanently in the region. Hence, radio listeners can commonly listen their language that is switched with Indonesian. Based on the observation, there are 10 data found. It is equal as code-mixing found in non-standard - standard Indonesian. About the data sample, it is shown below.

A: Rame kenangan era 90-an yang membuat kangen misalnya kelereng. Kita pernah punya kelereng. Naah. Kemudian juga kita punya gambaran yang sederhana ya waktu kita kecil. (There are a lot of memories of ninetieth which are nostalgic suh as playing marbles. Well, then we had a homely drawing in our childhood)

C: Satu dus mi gede ya.

(A large box of noodle, didn't we?)

A: Ya, saya dulu masih kecil tahun 90 an punya lima sampai 7 bungkus.

(Yeah, when I was child in $90^{\text {th }}$ I had 5 to 7 packages.)

\section{C: La kui salah sijine, pancen urip jaman mbiyen enak tenan.}

(That is one of them. Truly living in the past era is very comfortable.)

There are two participants which are $A$ and $C$ talking about their childhood. The conversation runs normally in Indonesian with enthusiasm of telling their past memory. Both have the same competency in Java language. After A stating he has 7 packages of noodle when he was child, $\mathrm{C}$ responds it by concluding that past life is really comfortable by using Javanese $L a$ kui salah sijine, pancen urip jaman mbiyen enak tenan. C wants to be more intimate and comfortable since A's statement match his feeling and idea. It is full sentence Javanese sentence that is separated from the previous code (Indonesian) and becomes an independent code. Therefore, it is considered as code-switching.

As seen in the data, code-switching is used by $\mathrm{C}$ (phone caller) due to the same language competency between both speaking participants. $C$ uses Javanese in replying $A$ statements because he feels more intimate to speak Javanese since $A$ is a Javanese too. The conversation content brings them to a talk they feel nostalgic 
and they miss from their childhood. In this case, code-switching is beneficial to unite two participants' feeling, especially for the same Javanese competency background. However, radio listeners that do not understand Javanese will not catch the idea. East Kalimantan people are occupied by different tribes so a Javanese language may not be familiar for non-Javanese.

During conversation between $A$ and $C$ in Indonesian language, there is also a mixed java code in the sentence. It happens 10 times that means equals to codeswitching finding. One of them are shown below.

C: Kalau belum adzan belum pulang.

(If adhan had not been declared,we will not go home.)

A: lya kalau adzannya setengah 6. Kalau adzannya setengah 7 udah gelap.

(Yeah, in case adhan stated at 6 pm. If it started at 6.30 pm it must be dark.)

C: Paling nyesek yo iku dibandingin sama ayam.

(The most annoying one is to be compared with chicken.)

Based on the conversation, $\mathrm{A}$ and $\mathrm{C}$ talk about what time they used to go home after playing together. Both of them tell that they will go home in the evening when maghrib adzan is declared or the sky go dark. Additionally, $\mathrm{C}$ inserts joke by stating paling nyesek yo iku dibandingin sama ayam. He compares going home is like chicken's daily activity. Yo iku is a phrase of java language that is included into insertion type of code-mixing. It is a Javanese phrase which is inserted within an Indonesian sentence.

\subsection{Indonesian - Kutainese}

Kutai tribe is the origin of East Kalimantan. The language spreads widely and can be found easily in almost every radio programs in East Kalimantan. While Indonesian language is used in communicating on air, still code-switching and codemixing found. For code-switching, there are 18 data found which is the most dominant of code-switching findings and code-mixing findings. Here is one of the code-switching data samples.

\section{A: Tadi baru ja nelpon. Apa dijual?}

(She just called just now. What did he she sell?)

C: Jaga ikan punya acilnya itu nah.

(Keeping her grandmother's fish)

A: Oh ya kah.

(Oh, are you sure?)

C: Jagakan warungnya. Kar, bagaimana kita ni kar. Kapan-kapan ajakin bungkar ke rumahnya nikmar tu nah

(Keeping her store. Kar, how are about us, Kar. Someday I will invite bungkar to go to nikmar's house.)

\section{A: Ndik nyaman ni nyawa kumpul dengan bini urang.}

(I feel bad to hang out with other man's wife.) 
The conversation above occurs between a phone caller $(C)$ and a radio announcer (A). It occurs at $7.00 \mathrm{pm}$ with non-serious situation. The bold sentence above is a code switched from Indonesian language to Kutainese. Meanwhile, this code is categorized into inter-sentential code-switching. The Kutainese sentence becomes an independent code coming after conversation in Indonesian language. The conversation is started and run in Indonesian. In friendly conversation C asks A to visit Nikmar house as stated in kapan-kapan ajakin bungkar ke rumahnya nikmar tu nah. But A refuses it politely by using Kutainese that means he feels unwell to hang out with other man's wife. This statement shows intimacy while giving a joke answer to $C$.

In conversation above, code-switching is used due to the speaker (A)'s intention. He switches his code for refusing C's invitation to visit their friend's house. Both of the participants are good in Kutainese so A switches to Kutainese to deliver his refusal smoothly with a wish $C$ tolerate it and not to be disappointed with it. In this case, code-mixing is beneficial for delivering an excuse by considering the feeling of speaking partner. However, for non-Kutainese or people who do not master Kutainese it will not be understandable.

In the same conversation there is also found code-mixing from Indonesian language to Kutainese. There are 11 data found during the radio program. For the data, the sample is shown as following.

C: Buat Isna buat dana. Apalagi ya. Buat johan yang lagi sakit.

(For Isna and Dana. Who else? For Johan that is getting sick.)

A: Sakit apa?

(What kind of sick does he get?)

C: Sakit batukan.

(cough)

A: Batukan tu obatnya bawang putih.

(Cough medicine is white onion.)

C: Diapain.

(How to use it?)

A: Dikunyah.

(to be chewed)

C: Siapa ndak?

(Anybody wants?)

A: Coba hak! Ndak cepat sekiloang ngunyah.

(Try it! If you want faster result, chew a kilo of it.)

The data above show a conversation in Indonesian language. $C$ states that his friend Johan got sick. A wants to know and gives him the proper medication. However, $\mathrm{C}$ wants to know how to use the medication so that $\mathrm{A}$ answers it by stating dikunyah. However, $\mathrm{C}$ expects another way instead of chewing onion by saying siapa 
ndak that means who wants. A still wants him to do what he suggests by using a sentence containing a mixed code hak. The type of code-mixing is insertion because hak is a Kutainese word which is inserted and becomes a part of Indonesian sentence. In this case, A uses Indonesian language with kutai style because hak is an interjection in Kutainese to add more power in getting someone to do something. Moreover, A keeps inserting jokes in his following sentence by stating that to make the effect faster his friend should chew one kilo of white union.

\subsection{Indonesian - English}

As an international language, English is also found switched and mixed in conversation broadcasted in East Kalimantan radio. There are two participants that have English competency in the conversation, such as this A1 (radio announcer 1) and A2 (radio announcer 2). Both are two participants of conversation that have and occasion to talk alternately during the radio program. In their talk there are 7 codeswitching data found. It is shown in one of part of their conversation below.

\section{C: Lalu salam persahabatan aja. Lagunya adakan mbak.}

(And then greeting of friendship. Is there any song?)

A: Ada kok.

(There is)

C: Ditunggu ya mbak' alin.

(Wait a moment Miss Alin.)

\section{A: Ok deh. Have a nice day, Lala.}

(Ok. Have a nice day Lala)

The conversation is performed by a radio announcer $(A)$ namely Alin and a phone caller $(\mathrm{C})$ namely Lala. Both of them are female. In this section of radio program $C$ sends regards to all name he mentions before and then she requests a song to play. In last statement, A closes the conversation by switching his sentence into English. The switching happens because first sentence A uses Indonesian which is "Ok deh" and then it is followed with the second sentence in English which is "Have a nice day, Lala". Although the sentences are uttered by the same person, it contains different idea and none of them becomes a part of the other code. The intersentential code means to wish Lala to get luck and happiness in the day. Meanwhile, that English use is to adjust her conversation style with $\mathrm{C}$ age which is still teenager. English symbolizes modernity which is closed to recent youth.

The short conversation between $\mathrm{A}$ and $\mathrm{C}$ indicates an Indonesian switched to English. It is caused by higher prestige of English use in Indonesia, especially East Kalimantan. A namely Alin is aware of her speaking partner (C namely Lala), situation and topic of conversation between them. The choice of English code is for better style in conversation since the speaking partner (C) are familiar with daily English conversation sentence such as "Have a nice day". Therefore, inserting English code in Indonesian conversation is beneficial to adjust higher prestige in her speaking style. However, the use of English should be followed by English competency so the speaking partner in radio or the radio listener can gain the idea. 
English code is also mixed in Pilihan Pendengar radio program. It occurs in a conversation between $\mathrm{A} 1$ and $\mathrm{A} 2$ about goals what they have achieved in the past. Totally, there are 11 data found indicating the use of Indonesian - English codemixing.

A1: Tidak punya cita-cita itu artinya tidak punya arah tujuan.

(Without dream there is no goal)

A2: Ya betul. Yang pasti Arah yang dicapai itu apa.

(That's right. Of course, the direction to reach is what)

A1: Ok pemirsa. Terpaksa arah tujuan kita ternyata flashback dulu ya.

(Ok, ladies and gentlemen. Our direction have to be flashback first.)

In conversation above, $\mathrm{A} 1$ and $\mathrm{A} 2$ have conversation in Indonesian language. They are educated people that have English competency. It is shown in the style of speaking by mixing Indonesian language with English. A1 uses word Ok instead of baiklah. Ok is an English word that is mixed with Indonesian word pemirsa so that it is addressed to people listening his speaking. The word is used to state agreement or to sympathize with his interlocutors (radio listeners). Furthermore, A1 is also mixed flashback with Indonesian in his next statement. With the mix of ok and flashback, it means A1 speaks Indonesian with English style. Both of them are insertion codemixing.

\subsection{Indonesian - Arabic}

Indonesian language is found to be switched and mixed with Arabic in Pilihan Pendengar radio program. Although both speaker and speaking partner are originally Indonesian, they master Arabic language. Thus in conversation using Indonesian language sometime they switch into Arabic language. For code-switching, this research finds 18 data. Most of them are familiar Arabic words using by Moslems. Here is one of the data.

C: Halo, selamat pagi SKJ. Manisnya aku, goyangannya aku.

(Hello, Good morning SKJ. My sweetness, my dance.)

A: Musiknya asyik, goyangannya asyik, mbak lalanya asyik.

(The music is fun, the dance is fun, Miss Lala is also fun.)

C: Apa kabarnya kak Alin.

(How are you, Miss Alin?)

\section{A: Baik. Alhamdulillah.}

(Good. Thank God.)

It is a piece of starting conversation between Alin as a radio announcer $(A)$ and Lala as a phone caller (C). It happens in the morning which is indicated by selamat pagi. Afterwards, C asks A's condition indicated by Apa kabarnya kak Alin. A answers it with an Indonesian sentence which is switched with Arabic word Alhamdulillah. It is considered code-switching because Alhamdulillah is a clause which is not a part of Indonesian code baik. Alhamdulillah means "all gratitude is for Allah". This Arabic code is uttered to show her gratitude for good condition stated in 
baik. Code-switching type found in the data above is called intra-sentential codemixing.

Alin as a radio Announcer $(A)$ switches a code to Arabic due to religious style. Alhamdulillah is an Arabic sentence to state something good while showing gratitude to Allah in Islam. Applying Alhamdulillah in her sentence indicates higher prestige of Arabic for Moslem to show thankfulness, especially when it comes to answer a question "how are you". Alhamdulillah is a short answer and it equals to "I am well, I am okay, I am good, etc). Thus, code-mixing application in this conversation can indicate one's belief or religion that she is Moslem with the choice of Arabic code. It is familiar in Indonesian society in which most of them are Moslem.

The next Arabic code is found mixed as a part of an Indonesian sentence. It becomes a part of Indonesian sentence structure. There are 4 data found about Indonesian - Arabic code-mixing.

C: Sibuk, soalnya dia besok sibuk resepsi pernikahannya.

(Busy, because she will celebrate her marital party.)

C: Wah, sudah mau menikah.

(Wow! Just married)

A: Sudah.

(Already)

C: Aduh lala gak tau nih mbak.

(Ouch! Lala don't know Miss.)

A: Iya, nanti kalau siaran kita ucapin selamat buat dia ya.

(Yeah, we will congratulate her next time.)

C: Ya, semoga bahagia selalu ya bisa menjadi keluarga yang sakinah mawadah wa rahmah $\mathrm{Ya}$.

(Yeah, hopefully they can have a peaceful, loving and caring family, right?)

The conversation above shows how an Arabic code is mixed within Indonesian noun clause. It can be seen from the last sentence stated by C. Sakinah mawadah wa rahmah are Arabic clause that becomes a part of Indonesian phrase (keluarga....) in Indonesian sentence. Therefore, sakinah mawadah wa rahmah is kind of insertion. Sakinah, mawadah wa rahmah is uttered by $C$ after knowing a friend of A getting married. The word group commonly is uttered as a wish that a newly married people will get peace and blessed in life.

\section{Conclusion}

After conducting analysis, there are four points to conclude the result. First, based on the language, there are five code-switching and code-mixing varieties, such as Indonesian - Indonesian (25 data), Indonesian - Javanese (20 data), Indonesian - Kutainese (29 data), Indonesian - English (18 data), and Indonesian - Arabic (22 data). Among them, Indonesian - Kutainese code-switching and code-mixing are the most frequent variety in the radio program. It implies that Kutainese as a local East 
Kalimantan language is the most influential code in communication by East Kalimantan People, notably via radio media.

Second, code-switching and code-mixing in East Kalimantan Radio program are caused by diglossia and bilingualism. The variety of code-switching and code-mixing that refers to diglossia is found in kind of non-standard Indonesian (L) - standard Indonesian $(\mathrm{H})$. Meanwhile, the other four varieties (Indonesian - Javanese, Indonesian - Kutainese, Indonesian - English and Indonesian - Arabic) are from bilingualism factor. It implies that variety of code in the radio is influenced by standard or non-standard of a language and competency of more than one languages, including national language (Indonesian), local language (Javanese and Kutainese) and international language (English and Arabic).

Third, code choice plays important role in communication. Switching a code from a language to another language brings benefits of conversation within East Kalimantan radio program. Based on the data, code-switching becomes a tool to express speaker purpose, such as to generate humour in plain conversation, to get more intimate with speaking partner, to adjust higher prestige in communication and to adjust show gratitude or thankfulness to God.

Finally, this research observes words, clause and sentences indicating codeswitching and code-mixing in East Kalimantan radio program. It contributes to enhance and deepen analysis about code-switching and code-mixing by considering its situational factors and social factors, especially from East Kalimantan radio program. There is still huge occasion for future research to advance the discussion about code-switching and code-mixing in radio from different region since it will provide various data with different social and situational factors.

\section{Acknowledgments}

Firstly, the author presents gratitude for Allah SWT that gives a lot of mercies and blessings for him to finish this paper. This paper is an obligatory for thesis exam that will be held this year, 2019. For parents who still consistently pray for the author and support the study, thanks so much. Without you, this will be harder to stand as a student while conducting researches for final study. Thanks to Mr. Djatmika and Sri Marmanto as co-authors who give a lot of suggestion and support to finish this paper. It will give full of happiness if this paper is accepted since it determines graduation. For all of friends who also struggle to conduct research, may God gives best result for your hard effort.

\section{References}

Alsahafi, M. (2016). Diglossia: An Overview of The Arabic Situation. International Journal of English Language and Linguistics Research, Vol. 4(4), 1-11.

Ansar, F. (2017). Code Switching and Code Mixing in Teaching-Learning Process. Jurnal Tadris Bahasa Inggris, Vo. 10 (1), 29-45.

Ayeomoni, M. O. (2006). Code-Switching and Code Mixing: Style of language Use in Childhood in Yoruba Speech Community. Nordic Journal of African Studies, 15(1): 90-99.

Bastiar, I., Marmanto, S., \& Sumarlam, S. (2018). Code-Switching in Selling and Buying at Segiri Market Samarinda, East Kalimantan: a Sociolinguistics Study. 
Lingua Cultura, 12(1), 83-88. https://doi.org/10.21512/lc.v12i1.4013

Caparaz, P., \& Gustilo, L. (2017). Communicative Aspects of Multilingual Code Switching in Computer-Mediated Communication. Indonesian Journal of Applied Linguistics, 7(2), 349-359. https://doi.org/10.17509/ijal.v7i2.8137

Hanafi, W. (2017). Diglosia Bahasa Arab Pesantren dan Upaya Pemertahanan Bahasa Daerah. Qalamuna, Vol. 10(2), 47-70.

Herawati. (2014). Wujud Alih Kode dalam Masyarakat Tutur Konjo di Sinjai. Adabbiyat, Vol. 8(1), 94-116.

Husnan, L. E. (2016). Functional Categories of Code Switching by Bajo Student in English Foreign Language Classroom. Aksara, Vol. 28(2), 253-268.

Mahsusi, J., Djatmika, \& Marmanto, S. (2017). Pemilihan Kode pada Mahasiswa Riau di Yogyakarta. Lingua, Vol. 14(2), 267-284.

Moleong, L. J. (2014). Metodologi Penelitian Kualitatif. Bandung: PT Remaja Rosda Karya.

Muysken, P. (2000). Bilingual Speech: A Typology of Code-Mixing. United Kingdom: Cambridge University Press.

Poplack, S. (1980). Sometimes I'll start a sentence in Spanish y termino en español. Linguistics, 18, 581-618.

Saddiyah, C., \& Rokhman, F. (2018). Diglossia in Javanese-Indonesia Senior High School Educational Domain: Sociolinguistics Study in Tegal Regency. Seloka: Jurnal Pendidikan Bahasa Dan Sastra Indonesia, 7(1), 9-17.

Subiyatningsih, F. (2018). PEMAKAIAN BAHASA PADA TEKS UCAPAN SELAMAT PAGI DI WHATSAPP. Vol. 16(2), 179-192.

Sufiani, \& Pujiati, T. (2018). Alih Kode dan Campur Kode pada Santriwati Ponpes Alquran Nurmedina di Pondok Cabe Tangerang Selatan. Jurnal Sasindo Unpam, Vol.6(1), 1-24.

Thesa, K. (2017). Penggunaan Alih Kode dalam Percakapan pada Jaringan Whatsapp oleh Mahasiswa KNB yang Berkuliah di Universitas Sebelas Maret. PRASASTI: Journal of Linguistics, Vol. 2(1), 89-101.

Wahidah, B. Y. K., Djatmika, \& Marmanto, S. (2017). Alih Kode dalam Interaksi di Lingkungan Pondok Pesantren Ulil Albaab: Kajian Sosiolinguistik. Cendekia. Vol. 11(2), 143-158

Wulandari, R., Marmanto, S., \& Sumarlam, S. (2016). Alih Kode Dalam Dialog Novel Surga Yang Tak Dirindukan Karya Asma Nadia. PRASASTI: Journal of Linguistics, 1(2), 359-378. https://doi.org/10.20961/prasasti.v1i2.1400

Yanti, D., Rusminto, N., \& Agustina, E. (2017). Alih Kode dan Campur Kode Siaran Radio 94.4 FM di Radio Lampung dan Implikasinya. Jurnal Kata, Vo. 5(2), 1-12.

Yuliana, N., Luziana, A. R., \& Sarwendah, P. (2016). Code-Mixing and CodeSwitching of Indonesian Celebrities: A Comparative Study. Lingua Cultura, 9(1), 47-54. https://doi.org/10.21512/lc.v9i1.761 